Екатерина ФУРМАН

Rosyjska Akademia Nauk, Moskwa

\title{
Кто и за какую интеграцию? (Отношение населения стран ЕС и СНГ к интеграции)
}

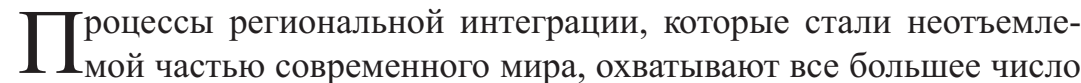
стран. Эта общемировая тенденция в определенной степени задает ориентиры всем участникам международной политики. С ней вынуждены считаться и те страны, которые в силу своего исторического развития оказались вовлечены в противоположный процесс, процесс дезинтеграции, как это произошло с бывшими республиками Советского Союза.

Наиболее быстро расширяющимся и углубляющим уровень интеграции (хотя провал референдума по Евроконституции ${ }^{1}$ и замедлил этот процесс) региональным объединением является Европейский Союз (ЕС). Он во многом стал примером региональной интеграции, осуществляемой во всем мире, по нему судят об успехе и от него отталкиваются при изучении подобных проектов и в других регионах. ЕС в значительной мере стал служить моделью и для интеграционных усилий на постсоветском пространстве, и его опыт стал основой для оценки этих усилий у российских исследователей ${ }^{2}$.

1 На референдумах во Франции и Нидерландах против утверждения проекта Европейской Конституции выступили 54,68\% французов (45,32\% проголосовали «за») и 61,6\% голландцев (38,4\% - «за»). The European Constitution: Post-referendum survey in France, Eurobarometer, http://europa.eu.int/comm/public_opinion/flash/fl171_en.pdf; The European Constitution: Post-referendum survey in the Netherlands, Eurobarometer, http://europa.eu.int/comm/public_opinion/flash/fl172_en.pdf.

2 «Единое экономическое пространство создается по схеме, которая типична для любого интеграционного объединения, включая Европейский Союз. Первый этап - создание таможенного союза, далее - общего рынка труда, капитала, рабочей силы, а затем высшая форма интеграции - валютный союз. Конечным же результатом формирования ЕЭП должно стать повышение 
Уникальность европейского интеграционного процесса заключается, прежде всего, в том, что это один из первых в истории наднациональных видов власти, предполагающий тесную экономическую и политическую взаимосвязь различных государств, которая базируется не на имперской, а на добровольной основе. И хотя в современном мире интеграцию недемократическим путем представить уже довольно сложно, но и сегодня формально одинаковые или очень близкие интеграционные планы могут иметь совершенно разное реальное политическое и социальное значение, в зависимости от того, какие страны вступают в интеграционные процессы, кто с кем интегрируется. Реальное значение тех или иных интеграционных планов и усилий становится зримым при сопоставлении их социальной поддержки в разных регионах. Цель данной статьи выявить и сравнить основные особенности и характерные черты социальной поддержки интеграционных процессов в Европе и на постсоветском пространстве.

Изначально у создателей Европейского Союза не было какого-либо четкого интеграционного плана ${ }^{3}$. Причиной его возникновения послужили последствия Второй мировой войны - осознание европейскими лидерами необходимости не допустить роста национализма в послевоенном мире и необходимость восстановления пошатнувшихся в результате войны экономик возглавляемых ими государств. Кроме того, с началом холодной войны сплочение рассматривалось и как важный шаг в сдерживании советского влияния в Западной Европе 4 .

благосостояния людей и создание предпосылок для развития экономик более высокими темпами». Т. Власовец, Беларусь - Казахстан - Россия - Украина: итоги и перспективы интеграции, Белорусское телеграфное агентство (БЕЛТА). http://belta.by/Analitica.nsf/Analytics/A38DB3A9989EFF9342256F6B002F4F5A?OpenDocument.

И. М. Коротченя пишет о том, что с 1992 г. Европейское сообщество было важным концептуальным источником в процессе формирования СНГ (см. И. М. Коротченя, Экономический союз суверенных государств: стратегия и тактика становления, Санкт-Петербургский университет экономики и финансов, СПб 1995, с. 38).

${ }^{3}$ В Декларации Р. Шумана говорилось «Европа не будет создана единовременно, в соответствии с единым планом. Она будет построена посредством конкретных достижений, которые сначала создадут солидарность де-факто». Цит. по В. Г. Шемятенков, Европейская интеграция, М. 2003, с. 325.

${ }^{4}$ Как пишет К. Андерсон: «Европейская интеграция предназначалась для осуществления кажется невозможной задачи: восстановление европейской 
Однако, как внутреевропейский процесс, интеграция, по мнению ее инициаторов, должна была быть вне политики и осуществляться как чисто рациональный и технократический проект ${ }^{5}$. В этих условиях учет политиками мнения населения многонациональной Европы о всех деталях интеграционного процесса мог только мешать и тормозить его ход. Клод Шейсон, бывший министр иностранных дел Франции и член Европейской Комиссии говорил: «Европа может быть создана только при условии отсутствия демократии» ${ }^{6}$. Интеграционная теория, включающая в себя несколько научных направлений, обосновывающих необходимость нового европейского и мирового порядка, которая создавалась в этот же период, также была ориентирована на разработку действий, прежде всего, элиты и не предполагала участия в интеграционном процессе населения ${ }^{7}$. И хотя социологические исследования, выявляющие отношение к интеграционному проекту населения в целом отдельных европейских стран проводились ${ }^{8}$, развернутых исследований, предполагающих анализ отношения к интеграции основных категорий населения по социально-демографическому признаку, долгое время просто не существовало. Отчасти это можно объяснить и тем, что создание Сообщества, целью которого было обеспечение мира, стабильности и благосостояния граждан, не могло не быть поддержано

экономики, привнесения мира, на континент, ранее раздираемый войнами, и установления демократии в странах с авторитарными традициями и недавним опытом тоталитаризма. Во многих отношениях ЕС должен был спасти европейцев от самих себя». С. Ј. Anderson, Consent and consensus: the contours of public opinion toward the euro, University of Notre Dame, Dec. 6-8, 2002, p. 5.

5 Д. Митрани, основатель функционализма, одного из основных научных направлений, составляющих интеграционную теорию, обвинял политиков и руководимое ими государство в том, что их целью является завоевание и удержание власти, а не забота об общественном благе. В. Г. Шемятенков, Европейская интеграция, с. 322.

6 M. Leonard, Rediscovering Europe, London 1998, p. 6.

7 «Искать помощи в исследованиях общественного мнения или определенных групп интересов так же бесполезно, как и не нужно... Достаточно выбрать и определить политические элиты стран, участвующих в интеграции, изучить их реакции на интеграцию и оценить изменения в их отношении в этой области». Е. Haas, The Uniting of Europe, Stanford University Press, Stanford 1968, p. 17.

8 Основной источник подобных исследований интеграционных настроений европейского населения - Евробарометер, отсчитывающий свое начало с 1973 г. 
практически всем европейским населением, что нашло свое отражение в термине «разрешающий консенсус», введенный в 1970 г. Л. Линдбергом и С. Шейнгольдом. Он означал общее согласие европейского населения с основными принципами проводимой политики, своего рода «мандат доверия», который позволял элитам предпринимать шаги в направлении строительства основ ЕС, не отвлекаясь на отношение к нему населения 9 .

Переломным событием в процессе европейской интеграции стало подписание Единого европейского акта (EEA) в 1985 г., который обозначил начало ее нового этапа, а именно, создание Европейского Союза на основе существующих Сообществ ${ }^{10}$ и углубление компетенции ЕС в области координации экономической, валютной, социальной политики, социально-экономического сплочения, исследований и технологического развития, защиты окружающей среды, а также развитие европейского сотрудничества в области внешней политики. Маастрихтский Договор о Европейском Союзе (ЕС) (1992 г.) не только дал Европейским сообщества новое название, но и законодательно закрепил озвученные в ЕЕА цели и ввел общее европейское гражданство ${ }^{11}$.

Одновременно с этим, начиная со второй половины 1991 г. периода окончательных переговоров и подписания Маастрихского договора - поддержка интеграции среди европейского населения начала быстро сокращаться вплоть до 1996 г., достигнув в большинстве стран ЕС своего самого низкого уровня за всю свою историю $48 \%$ граждан, считавших, что это «хорошо» и $17 \%$ - «плохо» $(28 \%-$

9 L. Lindberg, S. Scheingold, Europe's Would-Be Polity, Prentice Hall, Englewood Cliffs, NJ 1970.

10 Европейское объединение угля и стали (ЕОУС), Европейское экономическое сообщество (ЕЭС), Европейское сообщество по атомной энергии (Евратом).

${ }^{11}$ С 1 января 1993 г. официально начал функционировать Единый европейский рынок, ликвидировавший практически все барьеры для свободного движения в рамках ЕС людей, товаров, услуг и капитала. Со вступлением в силу 1 ноября 1993 г. Маастрихтского договора Сообщество сделало необратимый шаг к созданию Экономического и валютного союза (ЭВС), а также к введению единой валюты, с одной стороны, и достижению политического союза - с другой. Выполнение целей, содержащихся в Договоре (достижение четырех свобод, создание и проведение общей политики во все большем количестве областей), вело к постепенной передаче части суверенитета государств-членов европейским институтам. 
считали, что это «ни хорошо, ни плохо») ${ }^{12}$. При чем это произошло после того, как до этого падения, в марте 1991 г. уровень поддержки членства своей страны в Европейском Союзе среди европейского населения занял свою самую высокую позицию - 75\% граждан, считавших, что это «хорошо», при $3 \%$ - считающих, что это «плохо» $(19 \% \text { - «ни хорошо, ни плохо» })^{13}$.

Эти изменения в уровне поддержки стали особенно болезненны для процесса европейской интеграции, поскольку начались именно в тот момент, когда Европейский Союз вступил в наиболее активную фазу своего развития, при которой одобрение его деятельности населением становилось наиболее важным. Если до Маастрихта интеграционный процесс касался лишь «высокой политики» и затрагивал вопросы межгосударственного сотрудничества, то после него интеграция вызвала необходимость изменения внутриполитической жизни каждой из стран и стала затрагивать жизнь простых граждан непосредственно. В свою очередь, снижение уровня обсуждения вопросов европейской политики (от межправительственного до уровня каждого гражданина отдельной страны) делало их более спорными, поскольку спектр мнений становился более разнообразным и тем самым усложнял процесс принятия решений. А поскольку выработка Маастрихтского договора происходила по прежним стандартам межправительственных обсуждений, в то время как его содержание касалось уже внутриполитической жизни каждой из стран, это несоответствие вызвало у европейского населения особенно острое ощущение удаленности от него механизмов принятия решений, осуществляемых в ЕС. У европейских граждан стали возникать вопросы относительно политики совершенно разных уровней, начиная от продажи продуктов питания и напитков и заканчивая более важными проблемами, такими как характер системы распределения. Но главным из них стал вопрос о том, в каком направлении движется европейская интеграция и кто находится у ее руля ${ }^{14}$. Как показывали

12 Eurobarometer, Public opinion in the European Community, 46.1996, http://europa.eu.int/comm/public_opinion/archives/eb/eb46/eb46_en.pdf.

13 Eurobarometer, Public opinion in the European Community, 35. June 1991, http://europa.eu.int/comm/public_opinion/archives/eb/eb35/eb35_en.pdf.

14 Согласно опросу 1992 г. респонденты, которые считали себя информированными о ЕС, составили лишь 32\% населения стран его членов, $68 \%$ - напротив, ощущали недостаток в подобной информации. Только $19 \%$ респондентов сказали, что они достаточно хорошо осведомлены о Маастрихтском договоре, в то 
опросы населения, в 1992 г. только 14\% граждан ЕС были удовлетворены уровнем «демократического влияния», доступного им в институтах EC, в то время как $71 \%$ респондентов были им не удовлетворены ${ }^{15}$. Кроме того, в том же году впервые был зафиксирован численный перевес тех граждан ЕС, которые были не удовлетворены, как работает демократия в их собственной стране $(45 \%$ против 52\%). При этом те, кто был доволен работой демократии в своей стране, тем не менее, достаточно критично относились к работе демократических институтов самого ЕС (66\%), чуть менее, может быть, чем те, кто был ею не доволен $(78 \%)^{16}$.

Со временем, когда европейское население начало свыкаться с новым уровнем интеграции, он стал более привычным и воспринимался им уже как данность, а полномочия Европарламента постепенно расширялись ${ }^{17}$, уровень поддержки европейской интеграции среди граждан ЕС с 1996 г. стабилизировался в рамках фиксированного коридора от $48 \%$ до 56\% - считавших, что членство их страны в ЕС - это «хорошо», не опускаясь ниже уже достигнутой самой низкой планки, но и не дотягиваясь до прежних высот ${ }^{18}$. Таким образом, почти всеобщая поддержка интеграции, при которой основная масса населения не была посвящена в содержание европейской политики, сменилась более прагматичным к ней отношением, а количество граждан, удовлетворенных ходом демократии в ЕС, увеличилось с $35 \%$ в 1997 г. до 49\% в 2005 г. $^{19}$

время как $81 \%$ - что они знают о нем совсем немного (47\%), или только то, что подобный договор существует (28\%) (6\% - никогда до сегодняшнего дня о нем не слышали). Eurobarometer, Public opinion in the European Community, 35. June 1991, http://ec.europa.eu/public_opinion/archives/eb/eb35/eb35_en.pdf.

15 Eurobarometer, Public opinion in the European Community, 38. 1992, http://ec.europa.eu/public_opinion/archives/eb/eb38/eb38_en.pdf.

16 Там же.

17 Длительное время Европейский парламент выполнял лишь консультативные функции, и только с 1979 г. в него были проведены первые прямые выборы. Реформами Амстердамского договора (1997 г.) была усилена демократическая ответственность ЕС путем увеличения роли Европарламента и предоставления ему больших полномочий.

18 Eurobarometer, Public opinion in the European Community, 64, http://ec.europa.eu/public_opinion//archives/eb/eb64/eb64_first_en.pdf.

19 Eurobarometer, Public opinion in the European Community, 48. 1997; Eurobarometer, Public opinion in the European Community, 63. 2005, http://ec.europa.eu/public_opinion/archives/eb/eb48/eb48_en.pdf. 
Однако, вне зависимости от колебаний поддержки интеграции европейских граждан в целом, среди них всегда были те, кто поддерживал ее больше, а кто меньше, были и те, кто относился к ней настороженно и даже опасался ее. И, конечно, те, кто поддерживал интеграционный процесс, разделяли его основные цели и задачи и являлись своего рода основными его проводниками и носителями его характера. Кто же поддерживает европейский интеграционный процесс, кому на каждом его новом витке он приносит больше приобретений, чем потерь?

Таблица 1, приведенная ниже, демонстрирует данные опросов разных категорий населения, проведенных, как в период наиболее высокой (до Маастрихта), так и в период наиболее низкой поддержки ими интеграционного процесса.

Таблица 1

Отношение к членству своей страны в ЕС в 1991 и 1996 г. (\%)

\begin{tabular}{|c|c|c|c|c|c|c|c|c|c|}
\hline & & \multicolumn{2}{|c|}{ Хорошо } & \multicolumn{2}{|c|}{ Плохо } & \multicolumn{2}{|c|}{$\begin{array}{c}\text { Ни хорошо, } \\
\text { ни плохо }\end{array}$} & \multicolumn{2}{|c|}{ Не знаю } \\
\hline & & 1991 & 1996 & 1991 & 1996 & 1991 & 1996 & 1991 & 1996 \\
\hline \multirow{4}{*}{$\begin{array}{l}\text { Окончившие } \\
\text { образование }\end{array}$} & До 16 лет & 65 & 39 & 8 & 20 & 19 & 32 & 8 & 10 \\
\hline & От 16 до 19 лет & 70 & 46 & 7 & 18 & 19 & 29 & 4 & 8 \\
\hline & Старше 20 лет & 85 & 60 & 4 & 13 & 10 & 22 & 1 & 7 \\
\hline & Учащиеся & 81 & 63 & 1 & 9 & 15 & 22 & 3 & 7 \\
\hline \multirow[t]{4}{*}{ Возраст } & 15-24 лет & 75 & 52 & 3 & 13 & 19 & 27 & 5 & 10 \\
\hline & 25-39 лет & 75 & 52 & 5 & 14 & 17 & 27 & 3 & 7 \\
\hline & 40-54 лет & 74 & 47 & 6 & 19 & 16 & 28 & 4 & 6 \\
\hline & 55 лет и старше & 67 & 43 & 9 & 20 & 17 & 28 & 7 & 9 \\
\hline \multirow[t]{4}{*}{ Уровень дохода } & самый высокий & 80 & 59 & 5 & 13 & 13 & 23 & 2 & 6 \\
\hline & высокий & 75 & 48 & 6 & 17 & 16 & 28 & 3 & 6 \\
\hline & низкий & 72 & 43 & 8 & 17 & 17 & 32 & 4 & 8 \\
\hline & самый низкий & 65 & 40 & 8 & 20 & 20 & 32 & 7 & 9 \\
\hline
\end{tabular}

Источник: Eurobarometer, Public opinion in the European Community, ? 35 (1991) и ? 46 (1996); http://ec.europa.eu/public_opinion/archives/eb/eb35/eb35_en.pdf ; http://ec.europa.eu/public_opinion/archives/eb/eb46/eb46_en.pdf.

Мы видим, что разочарование в работе демократии и вообще в европейской политике в целом не сильно повлияло на соотношение сторонников и противников интеграции в каждой из выделенных 
социальных групп. Прежде всего, следует отметить, что и в 1991 г. (еще до падения поддержки) и в 1996 г. интеграцию в большей степени поддерживали более образованные, более обеспеченные и более молодые категории населения. При этом наиболее сильная зависимость голосования наблюдается с уровнем образования и неразрывно с ним связанным уровнем дохода. Здесь разница в поддержке между наиболее и наименее образованными слоями населения в 1991 г. составила 20 процентных пунктов (между окончившими образование до 16 лет и теми, кто это сделал после 20 лет). В 1996 г. разрыв между ними достигает 24 пунктов. Разница в поддержке между наиболее обеспеченными и наименее обеспеченными в 1991 г. и 1996 г. составляет 15 и 19 процентных пунктов, соответственно. Зависимость от возраста менее значительна: между самым молодым и самым старшим поколением разница в поддержке составляет 8 процентных пунктов в 1991 г. и 9 пунктов - в 1996 г. При этом, за рассматриваемый период между 1991 и 1996 гг. количество тех, кто считал, что членство их страны в ЕС - это «хорошо», больше всего сократилось среди наименее образованной категории населения, по сравнению с учащимися (разница между количеством тех, кто в 1996 г. перестал считать, что членство в ЕС - это «хорошо» в этих двух категориях составила 8 процентных пунктов) и наименее обеспеченной категории населения, по сравнению с наиболее обеспеченной (также 8 процентных пунктов), в то время как зависимость от возраста в сокращении количества считавших, что членство - это «хорошо», не прослеживается (разница в количестве разочаровавшихся между самой молодой и самой пожилой группой составляет 1 процентный пункт).

Таким образом, после Маастрихта, несмотря на общее падение поддержки интеграции, более негативно, чем другие категории населения, к ЕС стали относится менее образованные и менее обеспеченные граждане, те, кто и раньше его поддерживал реже остальных. А те категории населения, которые ранее более одобрительно относились к интеграционному процессу - наиболее образованные и обеспеченные граждане - в большей степени, чем другие, поддержали и его новую стадию - Маастрихтский договор. Это подтверждают и данные опроса, проведенного в 1992 г., в котором европейское население спрашивали о его согласии или несогласии с Маастрихтским договором при проведении возможного референдума, 43\% европейского населения проголосовало бы «за» договор, $27 \%$ - «про- 
тив» и $30 \%$ - не определились с ответом ${ }^{20}$. Без учета тех, кто не определился, ответы респондентов, согласно их социально-демографическому статусу, распределись следующим образом:

Таблица 2

При проведении референдума по вопросу согласия или несогласия на Маастрихтский договор Вы проголосуете «за» или «против»?

\begin{tabular}{|c|c|c|c|}
\hline & & «3a» & «Против» \\
\hline \multirow{4}{*}{$\begin{array}{l}\text { Окончившие } \\
\text { образование }\end{array}$} & До 16 лет & 57 & 43 \\
\hline & От 16 до 19 лет & 59 & 41 \\
\hline & Старше 20 лет & 71 & 29 \\
\hline & Учащиеся & 70 & 30 \\
\hline \multirow[t]{4}{*}{ Возраст } & 15-24 лет & 64 & 36 \\
\hline & 25-39 лет & 62 & 38 \\
\hline & 40-54 лет & 63 & 37 \\
\hline & 55 лет и старше & 60 & 40 \\
\hline \multirow[t]{3}{*}{ Вид деятельности } & Менеджеры & 72 & 28 \\
\hline & Самозанятые & 61 & 39 \\
\hline & Рабочие & 52 & 48 \\
\hline Всего & & 62 & 38 \\
\hline
\end{tabular}

Источник: Eurobarometer, Public opinion in the European Community, ? 38, 1992, http://ec.europa.eu/public_opinion/archives/eb/eb38/eb38_en.pdf.

Из приведенных данных мы можем заключить, что большое влияние на голосование оказывает вид деятельности респондента - за новый уровень интеграции в большей степени голосуют менеджеры и в наименьшей рабочие, разница в поддержке между которыми составляет 20 процентных пунктов, а также непосредственно связанный с ним уровень образования. Среди более образованных поддержка выше, чем среди менее образованных, и эта разница между ними составляет 14 процентных пунктов. Возрастной критерий, как и прежде, имеет наименьшее значение в степени поддержки этого этапа углубления интеграции. Наиболее молодое поколение прого-

20 Eurobarometer, Public opinion in the European Community, 38, 1992, http://ec.europa.eu/public_opinion/archives/eb/eb38/eb38_en.pdf. 
лосовало за Маастрихт на четыре процентных пункта больше, чем наиболее пожилое.

Поскольку основная задача европейской интеграции заключалась, прежде всего, в уничтожении барьеров для экономического обмена, облегчении передвижения капитала и труда, а также создании единой валюты, это, в свою очередь, способствовало увеличению международного замещения труда и постепенно лишало работы менее квалифицированных рабочих. Кроме того, рыночная либерализация подрывала жизнеспособность системы социального обеспечения. Не удивительно, как отмечают Г. Маркс и Л. Хуге ${ }^{21}$, что «рыночная либерализация оказалась наиболее выгодна для людей с высоким уровнем дохода, образования и профессиональных способностей», поскольку она поощряет тех, кто обладает высоким уровнем знаний и профессиональным опытом, и, напротив, наказывает тех, у кого их нет, или этот уровень низкий.

Однако, европейская интеграция, как уже отмечалось, не ограничивается экономической сферой, она затрагивает и все остальные области жизнедеятельности и по мере своего продвижения требует от людей все больше необходимых качеств и способностей, чтобы успешно функционировать на ее пространстве. Не удивительно, что количество тех, кто поддерживает каждый новый уровень интеграции, всегда меньше, чем тех, кто поддерживает интеграционный процесс в целом. Количество сторонников членства своей страны в Европейском союзе в 1992 г. было значительно больше - 60\% респондентов считали, что «членство их страны» - это «хорошо» ( $23 \%$ - что это «ни хорошо, ни плохо» и $12 \%$ - «плохо»), по сравнению с теми, кто голосовал за Маастрихт $(43 \%)^{22}$. Вот какие данные Евробарометра о соотношении одобрения евроинтеграции в целом и Маастрихтского договора (Таблица 3).

Как мы видим, сторонники ЕС значительно менее последовательны в одобрении ее новой стадии европейской интеграции, нежели его противники в своем нежелании ее дальнейшего продвижения. Процент тех, кто положительно относится к ЕС и при этом выступает за Маастрихт (64\%), значительно ниже процента тех, кто относится

21 G. Marks, L. Hooghe, National identity and support for European integration, Berlin 2003, p. 2.

22 Eurobarometer, Public opinion in the European Community, 38, 1992, http://ec.europa.eu/public_opinion/archives/eb/eb38/eb38_en.pdf. 
к ЕС отрицательно и также готов проголосовать против Маастрихта $(82 \%)$.

Таблица 3

Соотношение одобрения европейского населения интеграции в целом и Маастрихтского договора (\%)

\begin{tabular}{||c|c|c|c|c|c|c|c||}
\hline \hline \multirow{2}{*}{\multicolumn{2}{||c|}{ Отношение к ЕС }} & \multicolumn{5}{|c||}{ Отношение к Маастрихтскому договору } \\
\cline { 2 - 9 } & $\begin{array}{c}\text { Всего } \\
(100)\end{array}$ & & 43 & & 27 & & 30 \\
\hline Положительное & 55 & 64 & 82 & 12 & 24 & 24 & 45 \\
\hline Двойственное & 36 & 21 & 18 & 37 & 50 & 42 & 51 \\
\hline Отрицательное & 8 & 5 & 1 & 82 & 25 & 13 & 4 \\
\hline \hline
\end{tabular}

Источник: Eurobarometer, Public opinion in the European Community, ? 38, 1992, http://ec.europa.eu/public_opinion/archives/eb/eb38/eb38_en.pdf

Как мы видим, сторонники ЕС значительно менее последовательны в одобрении ее новой стадии европейской интеграции, нежели его противники в своем нежелании ее дальнейшего продвижения. Процент тех, кто положительно относится к ЕС и при этом выступает за Маастрихт (64\%), значительно ниже процента тех, кто относится к ЕС отрицательно и также готов проголосовать против Маастрихта $(82 \%)$.

Если посмотреть, на ответы сторонников и противников Маастрихта, то увидим, что, в свою очередь, его противники далеко не всегда выступают против интеграции в целом, то есть против ЕС. Только четверть противников Маастрихта (25\%) отрицательно относятся к интеграции в целом, в то время как почти такое же их количество (24\%) имеют положительное о ней мнение (ровно половина (50\%) противников Маастрихта имели двойственное отношение к ЕС). В свою очередь, сторонники Маастрихта в своем большинстве положительно относились к евроинтеграции (82\%).

Еще меньшее количество европейского населения готово поддержать расширение ЕС, и поляризация общества по этому вопросу достигает значительно больших размеров, чем по вопросу о Маaстрихте среди разных категорий населения. Однако, и на этом уровне интеграционного процесса за него выступают более образованные граждане, и социально-демографическая тенденция голосования в целом остается прежней. 
Таблица 4

Скажите, Вы «за» или «против» включения в Европейский Союз новых стран .......(\%)

\begin{tabular}{|c|c|c|c|c|}
\hline & & «За» & «Против» & «Не знаю» \\
\hline \multirow{4}{*}{$\begin{array}{l}\text { Окончившие } \\
\text { образование }\end{array}$} & До 15 лет & 40 & 38 & 20 \\
\hline & От 16 до 19 лет & 43 & 39 & 18 \\
\hline & Старше 20 лет & 54 & 31 & 15 \\
\hline & Учащиеся & 59 & 25 & 16 \\
\hline \multirow[t]{4}{*}{ Возраст } & $15-24$ лет & 53 & 29 & 18 \\
\hline & 25-39 лет & 51 & 33 & 17 \\
\hline & 40-54 лет & 46 & 38 & 16 \\
\hline & 55 лет и старше & 41 & 40 & 19 \\
\hline \multirow[t]{4}{*}{ Вид деятельности } & Менеджеры & 53 & 33 & 14 \\
\hline & Самозанятые & 49 & 37 & 14 \\
\hline & Рабочие & 45 & 36 & 19 \\
\hline & Пенсионеры & 41 & 42 & 17 \\
\hline Всего EU-15 & & 47 & 36 & 18 \\
\hline
\end{tabular}

Источник: Eurobarometer, Public opinion in the European Community, ? 60, 2003, http://europa.eu.int/comm/public_opinion/archives/eb/eb60/eb60_rapport_standard_en.pdf.

Каждый следующий этап интеграции как в плане углубления уровня интеграции (от Европейского объединения угля и стали до разработки Евроконституции), так и в плане расширения числа участников (от Европы 6 до Европы 25 и далее), вызывает новое сопротивление населения, которое все чаще задается вопросом, каковы границы этой интеграции. Вслед за рациональной оценкой того вклада, который она несет для национальных экономик, граждане начинают опасаться, что дальнейший процесс интеграции будет угрожать существованию их национальной идентичности. И те, кто вполне согласен с теперешним списком членов и теперешним уровнем интеграции, может быть категорически против расширения его на культурно чуждую Турцию и дальнейшего углубления, способного привести к окончательной утрате национальных суверенитетов.

То, что далеко не все, кто голосует за евроинтеграцию, поддерживают каждый ее новый виток говорят и следующие данные. 
Таблица 5

Отношение европейского населения к интеграционному процессу, в зависимости от его «расширения» или «углубления» (вычислено на основе ответов на вопросы, что

должно стать приоритетом европейской политики - введение единой валюты (углубление) или вступление в Союз новых членов(расширение) (\%)

\begin{tabular}{||l|c|c|c|c||}
\hline \hline & $\begin{array}{c}\text { Против } \\
\text { «расширения» }\end{array}$ & Не знают & $\begin{array}{c}\text { За } \\
\text { «расширение» }\end{array}$ & Всего \\
\hline Против «углубления» & 23,0 & 2,6 & 7,9 & 33,5 \\
\hline Не знают & 1,8 & 5,1 & 1,1 & 8,0 \\
\hline За «углубление» & 30,6 & 4,7 & 23,3 & 58,5 \\
\hline Всего & 55,4 & 12,3 & 32,2 & 100,0 \\
\hline
\end{tabular}

Источник: J. A. Karp, S. Bowler, Broadening and deepening or broadening versus deepening: The question of enlargement and Europe's «hesitant Europeans», „European Journal of Political Science" 2004, p. 22.

В этой Таблице представлены данные Евробарометра ?54 за ноябрь-декабрь 2000 г. в 15 странах - членах ЕС. Согласно им, можно сделать вывод, что значительно большее количество респондентов поддерживает углубление, нежели расширение интеграционного процесса в Европе. 58,5\% из них считают, что приоритетом должно стать введение единой валюты, в то время как только треть $(32,2 \%)-$ расширение ЕС. Ту же тенденцию демонстрируют респонденты, не определившиеся по какому-то одному из вопросов. Из них количество тех, кто поддерживает углубление, почти в два раза больше $(4,7 \%)$, чем тех, кто является его противниками $(2,6 \%)$.

Нежелание определенных категорий населения дальнейшего развития интеграционного процесса, а также стремление защитить свою нацию от контроля со стороны Брюсселя, нашло свое выражение в усилении за последние годы националистических настроений в европейских странах, а наличие популистских правых политических партий стало огромным источником этого евроскептицизма по всему Европейскому Союзу. Как видно из данных, приведенных П. Перрино в его исследовании, посвященном президентским выборам 2002 г. во Франции ${ }^{23}$, сторонниками правых, отдавшие свои голоса

23 П. Перрино, Крайне правые на президентских выборах 2000 г.: осознанная поддержка Национального фронта или протестное голосование?, „Мониторинг общественного мнения. Экономические и социальные перемены” 2 (64), 2003, 2 (64), 2003. 
в первом туре выборов за председателей Национального фронта Жана-Мари Ле Пена и Республиканского национального движения Броно Мегре, прежде всего являются люди занятые сельским хозяйством (26\%), ремесленниками и торговцами (19\%), а также рабочими (33\%) и служащими (20\%). Правые также популярны среди людей с достатком ниже среднего (27\%) и малообразованных $(25 \%)^{24}$. Категории людей, среди которых доля голосующих за них не поднимается выше $10 \%$ - это администраторы старшего звена и люди свободных профессий (9\%), а также те, кто получил высшее образование (10\%). Различие в возрастных группах практически не наблюдается ${ }^{25}$. Таким образом, результаты голосования за правых во Франции стали еще одним выражением общей для опросов о поддержке европейской интеграции тенденции. «За» интеграцию и «за» «открытое общество» выступают более образованные и высококвалифицированные граждане, «против» - малообразованные, представители менее квалифицированных профессий.

А теперь посмотрим, кто поддерживал и кто был против нового, более глубокого уровня интеграции, предусматриваемого Евроконституцией на проваливших Евроконституцию французском и нидерландском референдумах в 2005 г.

Как и в предыдущих опросах Евробарометра, мы вновь видим сильную и чёткую связь голосования с образованием - среди наименее образованных поддержка Евроконституции крайне низка, в то время как среди лиц с университетским дипломом она получила большинство. Евроконституцию поддержала социальная элита и её отвергли большинство рабочих и пенсионеров. Конституция прошла в Париже и была отвергнута в сельской местности. Правда, на этот раз молодёжь была более склонна голосовать против конституции, чем представители старшей возрастной группы.

24 «Это Франция», - пишет исследователь, - «больших городов, где сильно развита преступность и где большую долю населения составляют иммигранты. Именно жителей таких населенных пунктов тревожит незащищенность и сложности во взаимоотношениях с «чужаками». Кроме того, именно в этой части Франции располагаются старые промышленные районы, находящиеся в кризисе и переживающие длительный, мучительный процесс переориентации, приспособления к требованиям постиндустриального общества». Там же, с.18.

25 Там же, с. 20. 
Таблица 6

Результаты опроса, проведенного сразу после референдума по Евроконституции во Франции, 2005 г. (\%)

\begin{tabular}{|c|c|c|}
\hline & «3a» & «Против» \\
\hline Всего & 45 & 55 \\
\hline Коммерсанты, руководители предприятий & 67 & 33 \\
\hline Лица свободных профессий, интеллектуалы & 63 & 37 \\
\hline Рабочие & 34 & 66 \\
\hline Пенсионеры & 43 & 57 \\
\hline Лица с начальным образованием & 23 & 77 \\
\hline Лица с дипломом университета & 56 & 44 \\
\hline 18-24 года & 41 & 59 \\
\hline $25-39$ & 43 & 57 \\
\hline $40-54$ & 37 & 63 \\
\hline От 55 лет и старше & 54 & 46 \\
\hline Жители Парижа & 55 & 45 \\
\hline Жители сельской местности & 39 & 61 \\
\hline
\end{tabular}

Источник: „Libйration”, 2005, 21 mai, p. 8.

Схожую картину дают данные по Нидерландам. Здесь за конституцию были всего $38 \%$ и против - $62 \%$ населения, и она не получила большинства голосов ни в одной социально-демографической группе. Но фактор образования, как видно по опросу Евробарометра, проведенного после референдума, чётко виден и в нидерландском голосовании. Среди лиц, окончивших обучение ранее 15 лет, за конституцию голосовали $33 \%$, против - $67 \%$, среди окончивших образование в возрасте от 16 до 20 лет - 36\% «за» и 64\% «против», среди закончивших учиться после 20 лет - соответственно 43\% и 57\%. Так же, как и во Франции, меньше всего конституцию поддержали рабочие (22\% «за» и 78\% «против») и молодёжь от 18 до 24 лет (соответственно 26\% и $74 \%)^{26}$.

Конституция 2005 г. была попыткой сделать рывок вперёд, к более глубокому уровню интеграции. В своё время такой же попыткой, но удавшейся, был Маастрихтский договор 1992 г. И если сравнить голосование во Франции по Маастрихтскому договору (он был одо-

26 The European Constitution: Post-referendum survey in the Netherlands, Eurobarometer, http://europa.eu.int/comm/public_opinion/flash/fl172_en.pdf. 
брен 51\% французов) ${ }^{27}$ и голосование по Евроконституции, становится очевидно, что некоторые особенности социальной поддержки этих двух уровней и этапов интеграции меняются, но некоторые остаются прежними. Именно во Франции коммерсанты и руководители предприятий, поддержавшие Евроконституцию в 2005 г., в 1992 г. в большинстве своём голосовали против Маастрихта (51\%). Но и в 1992 г. поддержка интеграции лицами с университетским дипломом (71\%) и представителями свободных профессий и интеллектуалами (70\%) была гораздо выше средней, а лицами без диплома $(43 \%)$ и рабочими $(42 \%)-$ ниже.

В 1992 г. с трудом прошедший ратификацию Маастрихтский договор был таким же смелым шагом вперёд, к неизвестному будущему, как и в 2005 г. не прошедшая Евроконституция. Но сейчас договор 1992 г. стал уже нормой, частью привычного мира. И существующий уровень интеграции, созданный им, поддерживается значительно более широкими социальными слоями, чем в своё время поддерживался сам Маастрихт. Среди жителей Нидерландов, где за Евроконституцию выступили только $38 \%, 82 \%$ «скорее согласны» с тем, что членство их страны в ЕС - это «хорошо», а среди жителей Франции, где за Конституцию голосовали 45\%, таких - 88\%. Тем не менее, в распределении этих «скорее согласных» в разных социально-демографических группах этих стран видны те же тенденции, которые мы уже отметили ${ }^{28}$.

Поддержка европейской интеграции образованными людьми характерна не только для старых членов Европейского Союза. Очень

27 „Liberation” 2005, 21.05, p. 8; Eurobarometer 63, Public opinion in the European Union, http://europa.eu.int/comm/public_opinion/archives/eb/eb63/eb63_en.pdf.

28 Так в Нидерландах всего согласных с тем, что членство в ЕС - «хорошее дело» $-82 \%$ опрошенных. Но среди наименее образованной группы населения, окончившей обучение в возрасте до 15 лет, таких всего 72\%, а среди тех, кто обучался и после 20 лет - 88\%. Среди рабочих поддерживающих членство в ЕСвсего $73 \%$, среди жителей села - 76\%. Во Франции считают, что членство в ЕС «хорошее дело» $88 \%$ всего населения. Но среди жителей больших городов такого мнения придерживаются 90\% опрошенных, а в сельской местности всего 84\%. Если французская молодёжь не поддержала Евроконституцию, то в отношении к уже существующему уровню интеграции зависимость от возраста не видна, и молодёжь даже чуть больше (91\%) населения в целом считает ЕС «хорошим делом».

http://europa.eu.int/comm/public_opinion/archives/eb/eb63/eb63 en.htm. 
схожая картина предстаёт из данных опроса среди населения 13 стран-кандидатов в 2003 г. В связи с этим, можно утверждать, что сам характер европейской интеграции, нежели специфика только западноевропейского общества, определяют ее сторонников.

Удельный вес, считающих, что членство в ЕС - «хорошее дело», население 13 стран-кандидатов, 2003 г. (\%)

\begin{tabular}{|c|c|c|}
\hline Всего: & & 62 \\
\hline \multirow[t]{4}{*}{ Окончившие образование } & До 15 лет & 59 \\
\hline & От 15 до 20 лет & 60 \\
\hline & Старше 20 лет & 71 \\
\hline & Учащиеся & 70 \\
\hline \multirow[t]{4}{*}{ Возраст } & 15-24 лет & 70 \\
\hline & 25-39 лет & 67 \\
\hline & 40-54 лет & 61 \\
\hline & 55 лет и старше & 52 \\
\hline \multirow[t]{3}{*}{ Место жительства } & Сельская местность & 60 \\
\hline & Малый город & 62 \\
\hline & Большой город & 67 \\
\hline \multirow[t]{4}{*}{ Вид деятельности } & Менеджеры & 75 \\
\hline & Самозанятые & 65 \\
\hline & Рабочие & 62 \\
\hline & Пенсионеры & 52 \\
\hline
\end{tabular}

* В разных странах процент считающих, что членство в ЕС - «хорошее дело»-разный, но ни в одной стране он не меньше, чем удельный вес тех, кто считает, что это - «плохое дело».

Источник: Eurobarometer 2003, 4, Public opinion in the candidate countries. Full report, http://europa.eu.int/comm/public opinion/archives/cceb/2003/cceb2003.4 full report.pdf.

Таким образом, в разных странах - и старых членах ЕС и новых членах - и на разных этапах интеграции проявляются некоторые постоянные тенденции. Поддержка интеграции тесно связана с образованием, она максимальна у наиболее и минимальна у наименее образованных. Другие постоянные тенденции прямо связаны с этой зависимостью. Поддержка интеграции выше у лиц свободных профессий и интеллектуалов («по определению» наиболее образованных) и ниже у наименее образованных рабочих, выше у наиболее обеспеченных и ниже у мало обеспеченных. Она максимальна 
в больших городах - сосредоточении интеллектуальной жизни и минимальна в сельской местности.

Интеграционный процесс делит европейское общество согласно новым принципам. Это новое деление общества включает в себя, с одной стороны, людей, которые убеждены, что политическая, экономическая и культурная открытость несет больше выгод, чем потерь, а с другой - людей, которые относятся к этой открытости с опаской, настороженно или просто враждебно, полагая, что она может принести больше ущерба, если не сплошные минусы.

К началу 1990-х гг. Европейский Союз и Советский Союз подошли с разными, можно сказать противоположными, результатами своего развития. Европейский Союз в 1992 г. заключает Маастрисхтский договор, благодаря которому расширяет полномочия наднациональных институтов в экономической и политической областях. А Советский Союз, напротив, в 1991 г. распадается на составные части, и вместо него возникает Содружество Независимых Государств $(\text { СНГ })^{29}$. Тем не менее, усилия, которые предпринимают государства постсоветского пространства на пути к совместному сотрудничеству и созданию интеграционных группировок, и то, что эти усилия делаются во многом с оглядкой на европейский опыт интеграции, позволяют нам сравнить эти два процесса. А для этого необходимо понять, кто поддерживает интеграционный процесс на постсоветском пространстве.

К сожалению, мы не имеем данных о динамике отношения населения всех бывших советских республик к интеграционным проектам, которые создавались в период после распада Советского Союза, поскольку на постсоветском пространстве по этой теме не проводилось каких-либо согласованных и регулярных исследований. Сопоставимые данные по четырем бывшим советским республикам

29 Как пишет М.В. Стрежнева в своем исследовании, вышедшем в 1999 г., «если в ЕС на фоне относительно слабой социальной сплоченности в зоне интеграции в целом мы наблюдаем настойчивые и неустанные многолетние попытки перейти на более высокие ступени политической интеграции, то в постсоветском мире объединяющий потенциал остатков общей культуры и экономическая взаимозависимость остаются препятствиями к полному завершению политической дезинтеграции и сепаратному строительству национальных государств». М. В. Стрежнева, Европейский Союз и СНГ: сравнительный анализ институтов, М. 1999, с. 7, 8. 
- России, Белоруссии, Украине и Казахстану - появились совсем недавно. В 2004 г. начал работу «Евразийский монитор» (Барометр интеграции), проводящий исследования по интеграционным настроениям в этих четырех странах СНГ ${ }^{30}$. До этого исследования проводились только в отдельных странах постсоветского пространства и охватывали разные временные промежутки.

Прежде всего, следует отметить, что интеграция постсоветского пространства принципиально отличается от европейской в одном и очень важном аспекте. Если европейская интеграция не имеет никакой ясной модели в прошлом - подобного объединения в истории не существовало, то постсоветская «по определению» имеет такую модель. Это - СССР, в котором интеграция была очень высокой и была неразрывно связана со всеми другими аспектами советского тоталитарного общества. Кроме того, Беловежские соглашения, закрепившие создание новых независимых государств, были заключены в декабре 1991 г., после того, как почти все население Советского Союза в марте того же года проголосовало против распада страны. Как показали результаты общесоюзного референдума по вопросу о сохранении СССР 17 марта 1991 г., подавляющее большинство населения Советского Союза выступило «за» сохранение CССР (76,4\% участвовавших в голосовании $)^{31}$. Не удивительно, что

30 Всероссийский центр изучения общественного мнения (ВЦИОМ), используя свою базу данных (с 1989 г.) и связи с партнерами в странах бывшего $\mathrm{CCCP}$, выступил инициатором проекта «Евразийский монитор» («Барометр интеграции»). В его основу легли идеи «Евробарометра»- действующей программы Европейского Союза, и «Азиатского барометра», концепция реализации которого прорабатывается японскими специалистами. Пилотное исследование по проекту «Евразийский монитор», выявляющее отношение населения к интеграции в России, на Украине, в Беларуси и Казахстане, было проведено ВЦИОМом в апреле 2004 г. в сотрудничестве с социологическим центром «Новак» (Беларусь) и Донецким информационно-аналитическим центром (ДИАЦ). В сентябре 2004 г. был проведен второй тур опросов. На этот раз к проекту подключилась исследовательская группа «ЦИРКОН» (Россия), а также Казахстанский институт социально-экономической информации и прогнозирования (КИСЭИП). Третий тур опросов проведен в апреле 2005 г.

31 В РСФСР участвовало в голосовании 75,4\% взрослого населения, $71 \%$ ответили „да” сохранению СССР, на Украине соответственно - 83\% и 70\%, в Белоруссии - 83\% и 83\%, Узбекистане - 95\% и 93,7\%, Казахстане - $89 \%$ и 94\%, Азербайджане - 75\% и 93\%, Киргизии - 93\% и 94,5\%, Таджикистане - 94\% и $96 \%$, Туркменистане - 97,7\% и 98\%. Всего в референдуме приняли участие 
отношение к этому событию у большинства населения стран СНГ было окрашено глубоким чувством сожаления относительно произошедшего. Как показывают опросы Фонда Общественного мнения (ФОМ), на протяжении всего последующего десятилетия подавляющее количество россиян продолжали сожалеть о распаде Советского Союза: если в 1992 г. их число насчитывало 69\%, то в 1997 г. $84 \%$, а в $2001-79 \%{ }^{32}$. Опросы Евразийского Барометра за 2005 г. показали, что, чувства россиян разделяло большинство населения Беларуси и Украины, чуть меньше Казахстана:

Таблица 8

Отношение к распаду Советского Союза населения России, Беларуси, Украины и Казахстана, 2005 г. (\%)

\begin{tabular}{|l|c|c|c|c|}
\hline \multirow{2}{*}{$\begin{array}{l}\text { Скажите, пожалуйста, Вы лично сожалеете или не сожалеете, что Советский Союз } \\
\text { распался? }\end{array}$} \\
\hline & Россия & Беларусь & Украина & Казахстан \\
\hline Безусловно, сожалею & 42 & 29 & 33 & 19 \\
\hline Скорее сожалею & 25 & 26 & 20 & 22 \\
\hline Сожалею, всего & 67 & 55 & 52 & 41 \\
\hline Скорее не сожалею & 17 & 19 & 16 & 30 \\
\hline Безусловно, не сожалею & 7 & 13 & 20 & 19 \\
\hline Не сожалею, всего & 24 & 33 & 36 & 49 \\
\hline Затрудняюсь ответить & 9 & 12 & 12 & 10 \\
\hline \hline
\end{tabular}

Источник: ВЦИОМ, Пресс-выпуск ?345. http://www.wciom.ru/?pt=9\&article=2024.

Не удивляет и то, что, как показывают данные ФОМа за 2001 г., если бы россиянам предоставили возможность сейчас проголосовать на референдуме по объединению бывших союзных республик, за такое объединение также проголосовало бы большинство $(72 \%)^{33}$. Против него проголосовало бы $15 \%$ граждан России. Однако, при этом, большинство россиян в том же опросе все же признали, что восстановить СССР невозможно (58\%). Продолжали надеяться на возрождение Советского Союза $30 \%$ респондентов ${ }^{34}$. Насколько рав-

80\% избирателей страны, а высказались «за» сохранение СССР 61\% граждан, имеющих право голоса.

$32 \mathrm{http} / / /$ bd.fom.ru/report/cat/societas/society_power/referendum/of010901.

$33 \mathrm{http} / / /$ bd.fom.ru/report/cat/societas/society_power/referendum/tb010908.

34 Там же. 
номерно распределялись подобные настроения среди всех категорий населения демонстрирует следующая таблица, в которой даны ответы в зависимости от социально-демографического статуса опрашиваемых (Таблица 9).

Мы видим, что в наибольшей степени о распаде Советского Союза сожалеют пожилые люди старше 50 лет (89\%), по сравнению с молодыми от 18 до 35 лет (из них 61\% выразили свое сожаление по этому поводу), а также люди с более низким уровнем образования. Уровень дохода и место жительства респондентов в меньшей степени влияют на распределение ответов, или вообще не имеют особого значения. Несмотря на то, что в возможность воссоздания СССР, верит меньшинство россиян, среди этого меньшинства вновь больше представителей более старшего поколения, менее образованных граждан, менее обеспеченных, хотя уровень дохода играет здесь наименьшую роль, и жителей мегаполиса, чем жителей менее крупных городов и сел. Те же категории населения чаще других отвечают, что проголосовали бы за объединение союзных республик на предполагаемом референдуме, только в этом случае жители села в большей степени, нежели жители крупных городов, готовы проголосовать «за», хотя эта последняя тенденция выражена в меньшей степени.

Однако, несмотря на поддержку «объединения бывших союзных республик», эта формулировка, кроме некоего намека на бывшее союзное государство, все же не подразумевает под собой никакой конкретной модели объединения, поэтому каждый отвечавший мог вкладывать в нее свое собственное представление об этом. Выбор конкретных интеграционных группировок на постсоветском пространстве предлагается в других опросах, проводимых в рамках проекта «Евразийский монитор» в апреле 2004 г., которые раскрывают отношение жителей трёх славянских постоветских республик России, Украины и Беларуси - к нескольким типам интеграции или существования вне интеграционных группировок (Таблица 10).

Среди постсоветских типов интеграции в таблице упомянуты: 1) СССР и идея его восстановления, 2) СНГ, охватывающее все постсоветские страны, кроме Балтии и 3) экономический союз четырёх постсоветских стран: России, Украины, Беларуси и Казахстана (ЕЭП). Из данных таблицы мы видим, что поддержка всех форм интеграции на постсоветском пространстве - и утопического восстановления СССР, и экономического союза России, Украины, Беларуси 
Социально-демографические параметры отношения россиян к перспективе воссоздания Советского Союза. 2001 г. (\%)

\begin{tabular}{|c|c|c|c|c|c|c|c|}
\hline & & \multicolumn{2}{|c|}{$\begin{array}{l}\text { Скажите, пожалуйста, Вы лич- } \\
\text { но сожалеете или не сожалеете, } \\
\text { что Советский Союз распался? }\end{array}$} & \multicolumn{2}{|c|}{$\begin{array}{l}\text { Если бы сегодня проводился референдум } \\
\text { об объединении всех бывших союзных } \\
\text { республик, вы бы лично проголосовали за } \\
\text { объединение или против объединения? }\end{array}$} & \multicolumn{2}{|c|}{$\begin{array}{l}\text { По вашему мнению, сегодня } \\
\text { возможно или невозможно вос- } \\
\text { создание СССР? }\end{array}$} \\
\hline & & Сожалею & Не сожалею & За объединение & Против объединения & Возможно & Не возможно \\
\hline & Всего: & 79 & 15 & 72 & 15 & 30 & 58 \\
\hline \multirow[t]{3}{*}{ Возраст } & $18-35$ лет & 61 & 27 & 60 & 24 & 23 & 68 \\
\hline & 36-50 лет & 83 & 12 & 73 & 15 & 30 & 59 \\
\hline & старше 50 лет & 89 & 7 & 81 & 8 & 36 & 47 \\
\hline \multirow[t]{4}{*}{ Образование } & ниже среднего & 83 & 10 & 80 & 8 & 37 & 47 \\
\hline & среднее общее & 75 & 18 & 72 & 15 & 27 & 60 \\
\hline & $\begin{array}{l}\text { среднее } \\
\text { специальное }\end{array}$ & 82 & 13 & 70 & 19 & 29 & 61 \\
\hline & высшее & 72 & 22 & 67 & 20 & 31 & 60 \\
\hline \multirow[t]{3}{*}{ Доходы } & До 600 руб. & 79 & 14 & 74 & 14 & 30 & 59 \\
\hline & 600-1000 руб. & 85 & 12 & 77 & 13 & 33 & 53 \\
\hline & Более 1000 руб. & 75 & 19 & 67 & 18 & 27 & 63 \\
\hline \multirow{4}{*}{$\begin{array}{l}\text { Тип } \\
\text { населенного } \\
\text { пункта }\end{array}$} & Мегаполис & 79 & 17 & 68 & 22 & 38 & 54 \\
\hline & Большие города & 78 & 17 & 73 & 15 & 32 & 57 \\
\hline & Малые города & 79 & 13 & 73 & 13 & 28 & 57 \\
\hline & села & 79 & 15 & 75 & 14 & 29 & 58 \\
\hline
\end{tabular}

Источник: Фонд, Общественное мнение, http://bd.fom.ru/report/cat/societas/society_power/referendum/tb010908. 


\section{Отношение населения России, Украины и Беларуси к различным типам интеграции, 2004 г. (\%)}

\begin{tabular}{|c|c|c|c|c|c|c|c|c|c|c|c|c|c|}
\hline & & & $\begin{array}{r}\text { Уровень } \\
\text { обес }\end{array}$ & $\begin{array}{l}\text { иатери } \\
\text { еченно }\end{array}$ & льной & & & Возраст & & & Об & азова & \\
\hline & & Всего: & $\begin{array}{c}\text { скорее } \\
\text { хороший }\end{array}$ & $\begin{array}{l}\text { сред- } \\
\text { ний }\end{array}$ & $\begin{array}{c}\text { скорее } \\
\text { плохой }\end{array}$ & $18-25$ & $26-34$ & $35-44$ & $45-59$ & $\begin{array}{c}\text { старше } \\
60\end{array}$ & $\begin{array}{c}\text { началь- } \\
\text { ное }\end{array}$ & $\begin{array}{l}\text { сред- } \\
\text { нее }\end{array}$ & $\begin{array}{l}\text { выс- } \\
\text { шеe }\end{array}$ \\
\hline В объединенной & Россия & 10,7 & 16,1 & 10,2 & 9,8 & 22,0 & 18,0 & 10,7 & 8,1 & 1,7 & 5,6 & 12,2 & 14,2 \\
\hline Европе & Украина & 14,7 & 19,3 & 19,3 & 9,6 & 19,0 & 14,9 & 17,5 & 13,2 & 11,3 & 10,1 & 14,5 & 21,5 \\
\hline & Беларусь & 28,1 & 22,1 & 24,2 & 34,7 & 49,1 & 43,2 & 33,6 & 23,2 & 4,6 & 6,7 & 30,1 & 35,8 \\
\hline В объединенном союзе & Россия & 9,1 & 11,7 & 9,3 & 8,3 & 6,7 & 7,9 & 9,2 & 11,3 & 8,4 & 8,7 & 9,3 & 9,4 \\
\hline Белоруссии, России, & Украина & 23,0 & 14,1 & 21,1 & 26,3 & 19,6 & 23,4 & 20,0 & 25,7 & 24,9 & 20,9 & 24,8 & 23,7 \\
\hline & Беларусь & 17,1 & 15,6 & 16,9 & 17,0 & 8,0 & 10,5 & 13,6 & 22,4 & 25,3 & 19,5 & 17,1 & 15,7 \\
\hline В Содружестве Неза- & Россия & 6,9 & 8,3 & 7,7 & 5,5 & 4,5 & 10,4 & 6,6 & 8,1 & 4,5 & 4,7 & 7,6 & 8,2 \\
\hline висимых Государств & Украина & 11,1 & 13,3 & 10,6 & 11,1 & 11,6 & 12,3 & 12,6 & 11,3 & 8,7 & 10,4 & 11,4 & 11,6 \\
\hline & Беларусь & 6,8 & 6,5 & 6,2 & 7,4 & 5,7 & 7,4 & 7,0 & 4,4 & 9,2 & 10,7 & 5,8 & 7,0 \\
\hline Во вновь объединен- & Россия & 18,5 & 7,8 & 17,0 & 24,6 & 6,7 & 11,2 & 16,9 & 19,2 & 31,8 & 25,8 & 16,5 & 13,5 \\
\hline ном СССР & Украина & 18,6 & 9,6 & 14,7 & 24,0 & 14,9 & 16,1 & 18,5 & 17,3 & 23,9 & 23,1 & 19,7 & 10,9 \\
\hline & Беларусь & 15,2 & 23,4 & 15,4 & 14,5 & 6,3 & 10,5 & 10,7 & 12,8 & 31,0 & 27,5 & 14,6 & 10,0 \\
\hline В своей собственной & Россия & 50,5 & 51,1 & 53,1 & 45,9 & 57,0 & 48,2 & 53,7 & 48,7 & 48,5 & 49,2 & 50,9 & 51,3 \\
\hline стране & Украина & 32,4 & 43,7 & 34,3 & 28,8 & 34,8 & 32,5 & 31,5 & 32,6 & 31,3 & 35,1 & 29,4 & 32,4 \\
\hline & Беларусь & 27,8 & 29,9 & 33,7 & 19,5 & 24,0 & 27,2 & 29,0 & 32,0 & 24,9 & 28,2 & 27,5 & 27,5 \\
\hline
\end{tabular}

Источник: ВЦИОМ, Евразийский монитор, http://www.wciom.ru/?pt=156. 
и Казахстана, и СНГ - меньше, чем поддержка европейским населением европейской интеграции. Жить «в своей собственной стране» хотели бы половина россиян, а также чуть больше и чуть меньше трети граждан Украины и Беларуси соответственно. В «объединенной Европе» - почти треть граждан Беларуси, почти 15\% украинцев и $10,7 \%$ россиян $^{35}$.

Главное же отличие отношения к интеграции на постсоветском и на европейском пространствах - в социальной природе «групп поддержки». Поддержка идеи восстановления СССР на постсоветском пространстве, как и в приведенных выше опросах ФОМа, можно сказать, зеркально противоположна поддержке ЕС в Европе. За восстановление СССР выступают скорее более пожилые, мало обеспеченные (за исключением Беларуси) и менее образованные представители населения. Поддержка СНГ не имеет какой-либо ясной связи с социально-демографическими группами, за исключением России, где она, хотя и крайне слабая, но выше среди более обеспеченных и более образованных слоев населения. То же можно сказать и о поддержке «союза четырех», хотя связь с возрастом ясно прослеживается во всех трёх республиках, причём сторонниками как восстановления СССР, так и «союза четырех», выступает скорее пожилое население.

Таким образом, мы видим, что социальная поддержка ЕС в западно и центрально-европейских странах и социальная поддержка интеграции на постсоветском пространстве имеют разную социальную природу. Формально одна и та же идея интеграции является в этих двух регионах символом стремлений разных, даже противоположных социальных слоёв. Причем наиболее сильная зависимость голосования в Европе наблюдается с уровнем образования, а на постсоветском пространстве с возрастом респондентов.

Ностальгия по советскому государству, которая нашла свое выражение в сожалении большинства населения рассматриваемых стран о его распаде, длительное время не могла избавить постсоветскую интеграцию от стремления восстановить некое подобие Советского

35 В 2005 г., по данным того же Европейского Барометра, в «объединенной Европе» предпочли бы жить 14\% россиян, 30\% украинцев, 22\% белорусов и $12 \%$ казахов, «в своей собственной стране»- $30 \%$ россиян, $20 \%$ украинцев, $21 \%$ белорусов и 25\% казахов. Третья волна Евразийского монитора, http://www.wciom.ru/?pt=156. 
Союза. Как мы видим, идея восстановления СССР пользовалась наибольшей популярностью в России, на Украине она на втором месте после ЕЭП, а в Беларуси на два процентных пункта отстает от популярности «союза четырех». СНГ - наименее популярно во всех трех республиках ${ }^{36}$. Россия же - это то государство, для которого распад СССР, помимо территориальных и экономических потерь стал большим ударом по ее статусу «великой державы». Согласно опросу, проведенному Фондом «общественное мнение» в 2001 г. $71 \%$ россиян считали, что «Россия в целом проиграла от того, что Советский Союз распался» (только 15\% придерживались противоположной точки зрения), а $69 \%$ россиян продолжали хотеть видеть свою страну в качестве «великой и мирной державы» ${ }^{37}$. Подобные настроения создавали условия, при которых любая новая попытка со стороны России интегрироваться воспринималась как попытка вернуть славное прошлое. Это неоднократно демонстрировали и социологические опросы, согласно которым российские граждане склонны воспринимать СНГ как «суррогат» Советского Союза, и их отношение к этому межгосударственному объединению во многом окрашено ностальгическими чувствами. Так, результаты опроса ФОМ за 2005 г. подтверждают распространенность подобной схемы восприятия Содружества: 65\% опрошенных россиян хотели бы, чтобы большинство стран СНГ со временем объединились в одно государство. И главную роль в этом объединении россияне вновь отводят России ${ }^{38}: 53 \%$ россиян продолжали считать, что Россия должна играть в СНГ ведущую роль, что подразумевало неравные отношения между Россией и остальными странами СНГ (29\% высказали мнение, что в СНГ никто не должен играть ведущую роль,

36 По опросам, проведенным в апреле 2005 г., в СНГ предпочли бы жить чуть больше россиян $-11 \%$ и белорусов - 9\%, но меньше украинцев - 9\% и 19\% казахов. В ЕЭП - 15\% россиян, 24\% - белорусов, $26 \%$ - украинцев (во всех трех станах поддержка ЕЭП по сравнению с 2004 г. увеличилась) и 27\% - казахов. Третья волна Евразийского монитора, http://www.wciom.ru/?pt=156.

37 http://bd.fom.ru/report/cat/frontier/blocks/FSU/collapse_FSU/d020322 На открытый вопрос ФОМа в 2002 г., какой бы Вам больше всего хотелось видеть Россию в настоящее время, $69 \%$ россиян ответили: «чтобы стала великой и мирной державой». «Чтобы люди в стране жили лучше» хотели бы 13\% респондентов, «чтобы был порядок» - 7\%, «чтобы было, как в прошлом» - $2 \%$, не ответили 12\%. http://bd.fom.ru/report/cat/frontier/blocks/FSU/collapse_FSU/d020322.

38 http://bd.fom.ru/report/map/projects/dominant/dom0514/domt0514_3/d051424. 
что отношения между Россией и остальными странами СНГ должны быть равными, $18 \%$ респондентов затруднились с ответом) $)^{39}$.

То же касается и другого объединения на постсоветском пространстве. В 1997 г.. Союз России и Беларуси, соглашение о создании которого было подписано в 1996 г., одобренный большинством россиян (75\%), опять же большинством из них (59\%) считался первым шагом на пути восстановления СССР, за которым последует объединение других стран СНГ в единый Союз. Если бы к российско-белорусскому союзу присоединились и другие республики бывшего СССР, то это приветствовали бы $81 \%$ опрошенных граждан России в 1997 г. $^{40}$ То, что в перспективе при создании Союза России и Беларуси подразумевалось именно объединение в единое государство под началом России, подтверждают и опасения самих белорусов, которые в своем большинстве уверены, что российское руководство и российское население желают лишить Беларусь независимости. Так, на вопрос «На Ваш взгляд, хотят ли российские власти, чтобы Беларусь вошла в состав России, и перестала быть независимой страной?» 46,9\% населения республики ответили «да», а 26,5\% «нет» $(26,6 \%$ - не знали ответа). (Из числа белорусских лидеров и экспертов - 73\% - ответили «да», 20\% - «нет», 7\% - «не знали»). На вопрос, «На Ваш взгляд, хочет ли российское население, чтобы Беларусь вошла в состав России, и перестала быть независимой страной?»-39,2\% белорусов ответили «да», 26,8\% - «нет», 34\% -

39 Следует обратить внимание, что аргументация сторонников этой идеи, количество которых за последние полтора года, впрочем, сократилось на 20 п.п., - как и прежде, во многом основана на геополитических установках времен «холодной войны»: 17\% опрошенных при ответе на вопрос: «Почему вы считаете, что Россия должна стремиться к укреплению СНГ?» высказали мнение, что благодаря укреплению СНГ России будет легче противостоять любым возможным угрозам (в том числе и с Запада) - «вместе мы мощное государство и непобедимы»; «сильный кулак: как веник, когда все вместе, мы сильнее и трудно сломать нас», «будет крепче, мощнее, меньше к нам НАТО будет нос совать», «одной России тяжело против Запада». В ответах еще 9\% респондентов звучит ностальгия по СССР и отчетливые надежды на его восстановление посредством укрепления СНГ - «был когда-то СССР, и было хорошо; если ни к чему не стремиться, то ничего и не будет»; «может быть, опять СССР возродится, как раньше». http://bd.fom.ru/report/map/projects/dominant/dom0514/domt0514_3/d051424.

40 http://bd.fom.ru/report/cat/frontier/blocks/FSU/collapse_FSU/of19972502. 
не знали (лидеры и эксперты - 75\% - да, 13\% - нет, $12 \%$ - не знают) ${ }^{41}$.

При этом сохраняется прежняя тенденция в распределении ответов респондентов по социально-демографическому принципу. Чем моложе россиянин, тем с большей частотой он высказывает мнение, что в распаде СССР было что-то полезное. Так, среди респондентов в возрасте старше 55 лет их 16\%, среди тех, кому 46-54 года, $-19 \%$, среди тех, кому 26-45 лет - 31\%, в возрасте 25-35 лет - 47\%, а среди самых молодых (16-24 года) - 38\% $)^{42}$. А в Беларуси за объединение их страны с Россией в одно государство на предполагаемом референдуме в большей степени голосовали бы люди от 60 лет и старше - 37,3\%, нежели молодые люди от 16 до 19 лет (13,2\%) и менее образованные граждане $(35,1 \%$ - с начальным образованием, $35,3 \%$ с неполным средним и $22,1 \%$ - с высшим $)^{43}$.

Столь большую популярность идеи восстановления СССР, по сравнению с другими видами постсоветской интеграции, видимо, можно объяснить и тем, что этот тип интеграции был наиболее всем понятным и исходным примером, остальные же выполняли роль его плохих копий. Именно поэтому специфика поддержки населением постсоветского интеграционного процесса заключалась в том, что его поддерживало скорее пожилое население, которое большую часть своей жизни прожило в СССР и которое в наибольшей степени было проникнуто ностальгией по советскому прошлому, а также малообразованные и малообеспеченные слои населения, которым сложно было приспособиться и выживать в условия рыночной экономики.

Однако, устойчивость представления о постсоветском интеграционном процессе, как о возрождении бывшего СССР, постепенно начинает разрушаться. Кроме того, что российское население уже перестает верить в реалистичность планов воссоздания СССР, количество россиян, как показал опрос ФОМа за 2005 г., которые выступают за идею укрепления СНГ, значительно сократилось. Если в 1998 г. россиян, считавших, что Россия должна стремиться к укреплению СНГ, было 80\%, в 1999 г. - 85\%, в 2001 г. - 79\%, в 2003 г. $-86 \%$,

41 www.iiseps.org.

42 http://bd.fom.ru/report/cat/frontier/blocks/FSU/collapse_FSU/of19961803.

43 IISEPS NEWS (Новости НИСЭПИ), „Analytic Bulletin of Independent Institute of Socio-Economic and Political Studies” 2000, December, Issue 4 (18), c. 71. 
то в 2005 г. - их процент сократился на 20 пунктов, до $66 \%{ }^{44}$. При этом в опросе 2005 г., впервые за весь период мониторинга российского общественного мнения по этой проблеме, доля респондентов, считающих, что Россия выиграла от участия в СНГ (35\%), превзошла долю тех, кто полагает, что наша страна в целом от этого проиграла (27\%). Эти две тенденции последних опросов, по мнению Г. Кертмана, говорят об эрозии «ретроспективной» модели восприятия этого межгосударственного объединения. Ослабление установки на noвblшение уровня межгосударственной интеграции в СНГ - установки, органически связанной, повторим, с надеждами на полную или частичную реанимацию былой сверхдержавы, по мнению этого автора, - влечет за собой снижение требований к сегодняшнему уровню интеграции. А это, в свою очередь, ведет к ослаблению недовольства положением дел в СНГ в целом и тем, как участие в Содружестве отражается на нашей стране. Поэтому сочетание двух внешне разнонаправленных тенденций - к снижению доли стремящихся к укреплению СНГ и доли полагающих, что Россия проиграла от участия в нем, - в действительности является совершенно естественным: фактически это две стороны одной медали. В то же время, это предположение может служить объяснением, почему в России более образованные представители населения выступают в поддержку СНГ.

Кроме того, в аргументации сторонников укрепления СНГ за последний год, как отмечает тот же автор, основываясь на опросах ФОМа, все меньше звучит тема общего прошлого, и напротив все больше содержится принципиально иная, горазда более прагматичная мотивировка ориентации на укрепление СНГ. Говоря о необходимости дружбы и кооперации с соседями, респонденты апеллируют скорее к общности интересов, нежели к общности «корней». Но главное - страны, входящие в это объединение, описываются уже не как осколки единой ранее державы, а как самостоятельные субъекты международных отношений. «А такой подход предполагает и не-

44 На вопрос «как Вы считаете, Россия должна или не должна стремиться к укреплению СНГ» ответили «должна» в 1998 г. 80\% россиян $(10 \%$ - ответили «не должна», 10\% - затруднились с ответом), в 1999 г. - 85\% (7\% - «не должна», $8 \%$ - затруднились с ответом), в 2001 г. - 79\% (10\% и 12\% ответили «не должна» и затруднились с ответом соответственно), в 2003 г. - 86\% (7\%, и 7\%, соответственно) и в 2005 г. - 66\% (12\% и 23\%). http://bd.fom.ru/report/cat/frontier/blocks/FSU/d033931. 
сколько иное понимание логики взаимодействия этих стран: укрепление их взаимоотношений предстает не процессом «восстановления семьи» или, по крайней мере, устранения недоразумений и обид, накопившихся после «развода», а процессом выстраивания новых интеграционных структур на основе взаимных обязательств, балансировки интересов и т.д.», - отмечает Г. Кертман ${ }^{45}$.

В связи с этим возникает вопрос, возможно ли, что на постсоветском пространстве и на европейском пространстве сама по себе идея интеграции поддерживается разными и даже противоположными социальными слоями и группами. Те слои, которые в Западной и Центральной Европе хотят объединения, на постсоветском пространстве никаких объединений не желают и особенно ценят государственную самостоятельность? Или это различие относится не к идее интеграции вообще, а к её конкретным вариантам, и те, кто на постсоветском пространстве высказываются против постсоветской интеграции, выступают не против интеграции вообще, а именно против данной интеграции, данных, постсоветских стран? У нас есть возможность выяснить, какое из этих предположений верно.

В европейских странах не было альтернативных интеграционных проектов, в части интеграции с другими регионами. Но на постсоветском пространстве такой проект есть - идея вступления в каком-то более или менее отдалённом будущем в ЕС. Эта одна из реальных политических идей, и на Украине - даже официальный политический курс.

Таблица 10 приводит также данные о желании населения России, Украины и Беларуси жить в объединенной Европе. Кроме того, мы имеем данные об их поддержки идеи вступления их страны в ЕС (см. Таблица 11), благодаря которым можно установить, являются ли противники интеграции постсоветского пространства противниками интеграции вообще, или же они против объединения именно этого пространства, но за интеграцию их стран в объединённую Европу.

Как мы уже говорили, результаты опроса, приведенного в Таблице 10, показывают довольно большую привлекательность ЕС для населения постсоветских стран. Но поддержка вступления их стран в ЕС, что означает стремление жить одновременно и в объединённой Европе, и в своей собственной стране, распространено значительно

45 Г. Кертман, СНГ - между прошльм и настоящ⿻им, http://bd.fom.ru/report/map/articles/kertman/gur050408. 
больше. Среди россиян сторонников вступления их страны в ЕС в 2004 г. - 31,6\%, среди белорусов $-35,1 \%$, украинцев $-36,1 \%{ }^{46}$.

В зависимости от социального статуса, мы видим, что жить в ЕС скорее предпочитают более обеспеченные, молодые и образованные люди и, как видно из Таблицы 11, приведенной ниже, они же являются и сторонниками вступления России в ЕС, причём корреляции несомненные и значительные. Схожую картину, при несколько больших, чем в России, европейских симпатиях, мы видим и на Украине. Особенностью распространения проевропейских идей в Беларуси является то, что в этой стране за Европу голосуют скорее бедные, чем богатые. Возможно, это связано с тем, что белорусская экономика существенно отличается от российской и украинской большей ролью государства и вписавшиеся в эту централизованную экономику, достигшие в её условиях приличного материального достатка люди понимают, что им трудно было бы вписаться в основанную на иных принципах экономику ЕС. Но корреляция поддержки ЕС с образованием и возрастом в Беларуси - такая же несомненная и отчётливая, как в России и Украине.

Таблица 11

Поддержка вступления своей страны в ЕС (Россия, 2004 г., в \%)

\begin{tabular}{|c|c|c|c|c|}
\hline & & $\begin{array}{c}\text { За вступление } \\
\text { России в ЕС }\end{array}$ & $\begin{array}{l}\text { За вступление } \\
\text { Украины в ЕС }\end{array}$ & $\begin{array}{l}\text { За вступление } \\
\text { Беларуси в ЕС }\end{array}$ \\
\hline & Всего: & 31,6 & 36,1 & 35,1 \\
\hline \multirow{3}{*}{$\begin{array}{l}\text { Уровень } \\
\text { материальной } \\
\text { обеспеченности }\end{array}$} & Скорее хороший & 33,9 & 40,7 & 28,6 \\
\hline & Средний & 33,2 & 41,2 & 33,0 \\
\hline & Скорее плохой & 28,7 & 30,7 & 38,2 \\
\hline \multirow[t]{5}{*}{ Возраст } & $18-25$ лет & 33,6 & 39,0 & 50,3 \\
\hline & $26-34$ & 36,7 & 32,5 & 43,2 \\
\hline & $35-44$ & 34,9 & 39,4 & 41,1 \\
\hline & $45-59$ & 33,1 & 37,2 & 32,8 \\
\hline & Старше 60 & 22,0 & 33,3 & 15,7 \\
\hline \multirow[t]{3}{*}{ Образование } & Высшее & 40,1 & 39,3 & 44,1 \\
\hline & Среднее & 32,5 & 35,4 & 35,8 \\
\hline & Начальное & 24,1 & 34,5 & 15,4 \\
\hline
\end{tabular}

Источник: ВЦИОМ, Евразийский монитор, http://www.wciom.ru/?pt=156.

$46 \mathrm{http}: / / w w w . w c i o m . r u / ? \mathrm{pt}=156$. 
Итак, мы видим, что идея интеграции с ЕС выступает на постсоветском пространстве как альтернатива идее постсоветской интеграции. Интеграция с ЕС поддерживается более молодыми, образованными и обеспеченными людьми. Интеграция на постсоветском пространстве - их социальными антиподами. Те, кто против постсоветской интеграции, - не против интеграции вообще. Они - за другую интеграцию, за интеграцию в рамках альтернативных проектов.

Чем объяснить различия в социальной поддержке интеграционных процессов в Европе и на постсоветском пространстве?

Евроинтеграция - процесс новый, не имеющий прецедентов. Это - путешествие в неизвестное будущее. Не ясно, где и на чём она должна остановиться, будет ли ЕС охватывать всю европейскую территорию, включая Турцию, Украину и, кто знает, может быть и Россию, приведёт ли она к единому супергосударству и какие институциональные формы это супергосударство может принять. Ясно, что поддержка такого процесса требует открытого неопределённому будущему, не традиционалистского и терпимого к культурным различиям сознания. Но это и есть сознание, которое вырабатывается в процессе получения образования. Образованные люди концентрируются в больших городах, многие из них занимаются интеллектуальной работой. И, наоборот, - естественно, что те, кто боятся этой неопределённости будущего, кто стремится сохранить привычные, традиционные формы жизни, концентрируются на противоположном социальном полюсе.

Как двести лет назад парижский читатель газет был республиканцем, а бретонские крестьяне боролись за короля и церковь, так и сейчас парижский пользователь интернетом - скорее за евроинтеграцию, а крестьянин в той же Бретани или рабочий в маленьком провинциальном городке - скорее против.

Постсоветская интеграция, напротив, имеет ясную модель в прошлом - СССР. И понятно, что социальная база поддержки идеи восстановления СССР - прямо противоположна социальной базе поддержки европейской интеграции, как в самой Европе, так и в постсоветских странах, где образ устремлённого в неизведанное будущее ЕС привлекает те же социальные слои.

Конечно, ни СНГ, ни Единое экономическое пространство - не является восстановлением СССР. Но всё равно «образ» СССР довлеет над этими формами интеграции, которые воспринимаются как 
частичное, неполное, но всё же восстановление прошлого. Наименьшая связь с образом СССР - у модели «союза четырех» и социальная база этой идеи не имеет столь выраженного характера противоположности социальной базы европейской интеграции. Тем не менее, и идея «союза четырех» привлекает скорее представителей старшего поколения.

С разной ориентацией европейской и постсоветской интеграции на прошлое и будущее в массовом сознании населения связан ещё один, усиливающий эти ориентации аспект. Ядро ЕС - страны с развитой демократией и развитой рыночной экономикой. Стремление войти в союз с ними для других, менее развитых стран - это стремление «подтянуться» к их уровню. Естественным центром любого постсоветского объединения является Россия, страна с не слишком развитой экономикой и «управляемой» демократией. Стремление войти в союз с ней может скорее восприниматься как стремление зафиксировать теперешний уровень развития рыночных и политических институтов. Тем более, что на постсоветском пространстве Россия всегда поддерживает существующие политические режимы.

\section{Summary}

Integration processes in the European Union and in the Commonwealth of Independent States (CIS) are an element of a global tendency to form suprastate associations. Although such associations assume that supranational systems of authorities are created they are hardly antidemocratic. Nevertheless, each such integration process, although formally identical or highly similar, may have a completely different political or social significance which can be observed when their social support is compared. The European Union is practically unprecedented, and such a model of integration is being created for the first time in response to the requirements and needs of modern European society; it also has no determined borders. It mainly finds support among the young and educated social strata, who are interested in the benefits generated by such integration and who do not fear potential instability and indeterminacy that accompany such processes.

The Post-Soviet countries do have recent experience of integration having followed a model of a state with a highly integrated social and political life. The experience of the Soviet Union in many respects determines the directions of integration of these states although the USSR collapsed and the historic circumstances that affected its foundation are radically different. The nature of such integration efforts is reflected by their social support. The main advocates of the integration processes in CIS are older and less educated people for whom the revival of Soviet reality seems more attractive whereas the present brings risk and threat.

Thus being oriented to the past or to the future is among the main factors that differentiate the nature, efficiency and future prospects of these two integration processes. 